•KOSnเn" JIK. Vol. 7 No. 1 Mei 2019

\title{
HUBUNGAN TINGKAT PENGETAHUAN TENTANG ANEMIA DENGAN TINDAKAN PENCEGAHAN ANEMIA UNTUK PERSIAPAN KEHAMILAN PADA PASANGAN USIA SUBUR
}

\author{
Sri Aminingsih ${ }^{1}$, Alfinda Choirul Putra ${ }^{2}$
}

\begin{abstract}
Background: According to Fuady and Bangun's research (2013) iron deficiency anemia in pregnancy is the condition of mothers with hemoglobin levels below $11 \mathrm{gr} \%$ in the first and third trimesters or hemoglobin levels $<10.5 \mathrm{gr} \%$ in the second trimester and is one of the causes of death in pregnant women. In Indonesia the prevalence of pregnancy anemia is relatively high, which is $38 \%-71.5 \%$ with an average of $63.5 \%$. The results of the analysis in this study knowledge affect the adherence of respondents with $p=0.011$ $(p<0.05)$. From the initial survey in Slogoretno Jatisrono Wonogiri Village conducted by researcher in 3 couples of childbearing age, only 1 mother had enough knowledge about anemia.

The purpose: Describing the relationship between Knowledge Level About Anemia with Prevention Anemia for pregnancy preparation in couples of childbearing age.

The research is analytic with correlation design, this study aimed to analyze the relationship of knowledge about anemia as the independent variable and anemia prevention for pregnancy preparation as the dependent variable with the number of respondents 55 people. The results of the study using the Chi-Square Correlation Test obtained $p$ at 0,000

Results: Couples of childbearing age with high knowledge level were 40 respondents $(72.73 \%)$, while those with low knowledge level were 15 respondents $(27.27 \%)$. Prevent anemia performed optimally by couples of childbearing age were 28 respondents $(50.91 \%)$ while anemia prevention measures were less than 27 respondents $(49.09 \%)$.

The Conclusion: There is a relationship between knowledge level about anemia with anemia prevention for preparation of pregnancy in couples of childbearing age.
\end{abstract}

Keywords: Knowledge about anemia, anemia prevention

\section{PENDAHULUAN}

Zat besi merupakan pembentuk sel darah merah yang berhubungan dengan hemoglobin dalam anemia pada ibu hamil. Kehamilan adalah suatu kondisi seorang wanita memiliki janin yang tengah tumbuh dalam tubuhnya. Umumnya janin tumbuh di dalam rahim. Waktu hamil pada manusia sekitar 40 minggu atau 9 bulan. Kurun waktu tersebut, dihitung saat awal periode menstruasi yang terakhir hingga melahirkan. Kehamilan adalah salah satu masa yang membutuhkan adaptasi baik secara fisiologis dan psikologis (Molika, 2015). Zat besi dibutuhkan selama kehamilan untuk bayi, plasenta dan peningkatan jumlah sel darah merah pada wanita hamil untuk menutupi kebutuhan zat besi, ekspansi sel darah merah bergantung pada aliran besi dari cadangan, diet dan suplementasi besi. Jika zat besi yang tersedia mencukupi, ekspansi sel darah merah diperlukan sekitar $450 \mathrm{mg}$ pada wanita dengan berat badan 55 $\mathrm{kg}$. Total kebutuhan zat besi selama kehamilan sekitar 1000 mg. Jika cadangan besi kosong, total kebutuhan zat besi selama kehamilan harus dipenuhi dari diet dan suplementasi (Ani, 2013).

Dua penyebab anemia yang paling sering selama kehamilan dan nifas adalah defisiensi besi dan kehilangan darah akut. Sering kali keduanya sangat terkait erat, 
karena kehilangan darah yang banyak bersamaan dengan kehilangan besi hemoglobin dan kehabisan simpanan besi pada satu kehamilan dapat menjadi penyebab penting anemia defisiensi besi pada kehamilan berikutnya. Pada gestasi yang biasa dengan satu janin, kebutuhan maternal total akan besi yang diinduksi oleh kehamilan ratarata mendekati $1000 \mathrm{mg}$, yang sangat melebihi simpanan besi sebagian besar perempuan. Jika perbedaan antara jumlah besi yang disimpan untuk ibu dan kebutuhan besi pada kehamilan normal tidak dikompensasi melalui absorpsi besi dari saluran pencernaan, terjadi anemia defisensi besi. Karena jumlah besi yang diberikan ke janin dari ibu yang kekurangan besi tidak jauh berbeda dari jumlah yang ditransfer secara normal, bayi baru lahir dengan ibu hamil yang mengalami anemia berat tidak menderita anemia defisensi besi (Leveno, et al, ed., 2016).

Anemia defisiensi besi merupakan anemia yang paling sering dijumpai terutama di negara-negara tropik atau negara dunia ketiga karena sangat berkaitan erat dengan taraf sosial ekonomi. Anemia ini mengenai lebih dari sepertiga penduduk dunia yang memberikan dampak kesehatan yang sangat merugikan serta dampak sosial yang cukup serius. (Bakta, 2017).

Data Survei Kesehatan Rumah Tangga (SKRT) tahun 2001 menunjukkan anemia pada ibu hamil masih cukup tinggi, sebesar 40,1\%. Pada Riskesdas tahun 2010, tidak tersedia data anemia pada ibu hamil. Penelitian di Semarang pada tahun 2010 menemukan $48,7 \%$ ibu hamil mengalami anemia. Sebesar $61,8 \%$ ibu hamil di Demak mengalami anemia dengan $\mathrm{Hb}<11 \mathrm{mg} / \mathrm{dl}$ (Fathonah, 2016).

Dampak yang lebih jauh ditemukan adalah penurunan kualitas sumber daya manusia, penurunan produktivitas kerja, serta implikasi ekonomis. Secara ekonomis, dampak ADB pada kehamilan dapat dihitung, berdasarkan perkiraan biaya yang harus dikeluarkan bila terkena dampak ADB pada kehamilan. Upaya penanggulangan ADB telah dilakukan oleh pemerintah melalui program pemberian tablet zat besi pada wanita hamil, tetapi upaya tersebut belum memberikan hasil yang memuaskan. Beberapa studi melaporkan kegagalan upaya penanggulangan ADB pada wanita hamil, seperti masih ditemukannya abortus, prematuritas, dan pertumbuhan janin terhambat yang disebabkan oleh efek ADB pada wanita hamil. Jumlah wanita prahamil di tiap-tiap kabupaten berkisar antara $7-8 \%$. Wanita baru menikah akan mengalami kehamilan setelah 6 bulan pertama sebanyak $50 \%$, 1 tahun pertama sebanyak $75 \%$ dan lebih dari 1 tahun pertama sebanyak $90 \%$. Pada masa ini pemberian tablet zat besi diharapkan dapat mengisi cadangan besi tubuh sehingga bila mulai hamil cadangan besi tubuh telah tersedia untuk memenuhi kebutuhan zat besi selama kehamilan (Ani, 2013).

Menurut penelitian Fuady dan Bangun (2013) anemia defisiensi besi dalam kehamilan adalah kondisi ibu dengan kadar hemoglobin di bawah 11 gr\% pada trimester I dan III atau kadar hemoglobin < 10,5 gr\% pada trimester II dan merupakan salah satu penyebab kematian pada ibu hamil. Di Indonesia prevalensi anemia kehamilan relatif tinggi, yaitu $38 \%$ - $71,5 \%$ dengan rata-rata $63,5 \%$. Hasil analisis pada penelitian ini pengetahuan berpengaruh terhadap kepatuhan responden dengan $p=0,011$ $(p<0,05)$. Sedangkan untuk faktor umur $\quad(p=0,684), \quad$ kehamilan 
$(p=0,242)$, tingkat pendidikan terakhir $(p=0,096)$, dan pekerjaan $(0,495)$ tidak berpengaruh terhadap kepatuhan responden $(p>0,05)$. Pengetahuan berpengaruh secara signifikan terhadap kepatuhan ibu hamil dalam mengkonsumsi tablet zat besi sehingga perlu ditingkatkan edukasi ibu hamil mengenai anemia defisiensi besi pada ibu hamil.

Menurut penelitian Prapitasari (2013), untuk mengetahui hubungan antara tingkat pengetahuan anemia dan sikap wanita hamil dalam mengkonsumsi tablet besi di Puskesmas Kerjo di Kabupaten Karanganyar pada tahun 2011, berdasarkan analisis univariat, responden yang memiliki pengetahuan tentang anemia yang tinggi yaitu $38,8 \%$ dan responden memiliki sikap yang tinggi yaitu $34,7 \%$. Hasil pemeriksaan kadar hemoglobin $63,3 \%$ dari subyek normal, dan pemeriksaan kadar hemoglobin ini biasanya tidak dikenai biaya. Hasil Pearson Product Moment Uji korelasi pengetahuan anemia $p$ value = 0,132 dan sikap ibu hamil $p=0,638$. Sedangkan menurut penelitian Wuryanti 2010, tercatat jumlah AKI (Angka Kematian lbu) $100,04 / 100000$ kelahiran hidup. Penyebab kematian maternal diantaranya satu karena perdarahan, dua karena eklamsia dan sisanya disebabkan karena penyakit lain. Penelitian lain yang serupa dilakukan oleh Iswanto (2012), yang berjudul hubungan pengetahuan ibu hamil tentang anemia defisiensi besi dengan kepatuhan mengkonsumsi tablet besi di Puskesmas Karangdowo Klaten. Penelitian ini merupakan penelitian observasional analitik dengan pendekatan cross sectional, analisis data menggunakan uji ChiSquare. Jumlah sampel sebanyak 88 responden. Hasil penelitian menunjukkan terdapat hubungan yang signifikan antara pengetahuan ibu hamil tentang anemia defisiensi besi dengan kepatuhan mengkonsumsi tablet besi di Puskesmas Karangdowo Klaten. Penelitian yang setipe juga dilakukan oleh Muzayana, Santoso, dan Noviawati (2016), penelitian ini berjudul hubungan tingkat pengetahuan dengan kejadian anemia pada ibu hamil di wilayah Puskesmas Godean I. Jenis penelitian ini adalah penelitian analitik observasional. Desain penelitian yang digunakan adalah cross sectional, dengan uji statistik Chi Square. Hasil penelitian ada hubungan antara pengetahuan ibu hamil tentang anemia dengan pencegahan anemia.

Dari survei awal di Desa Slogoretno Jatisrono Wonogiri yang dilakukan peneliti pada 3 pasangan usia subur, ternyata hanya 1 ibu usia produktif yang mempunyai pengetahuan cukup tentang anemia. Penelitian ini adalah replikasi dari penelitian sebelumnya meskipun ada sedikit perbedaan variabel yaitu tentang kepatuhan mengkonsumsi tablet besi sedangkan yang akan diteliti pada penelitian ini adalah pengetahuan tentang anemia dengan tindakan pencegahan anemia.

\section{TUJUAN PENELITIAN}

Mengetahui hubungan tingkat pengetahuan tentang anemia dengan tindakan pencegahan anemia untuk persiapan kehamilan pada pasangan usia subur.

\section{METODE PENELITIAN}

Pada penelitian ini penulis menggunakan desain penelitian korelasi dengan pendekatan metode cross sectional. Alat ukur tingkat pengetahuan dan tindakan pencegahan anemia menggunakan kuesioner dan analisa data menggunakan Uji Chi-Square. 
POPULASI, SAMPEL, DAN TEKNIK SAMPLING

Populasi pada penelitian ini adalah semua ibu yang melakukan persiapan kehamilan pada bulan Januari-Maret 2019 berjumlah 55 responden, teknik sampling yang digunakan adalah dengan teknik sampling jenuh.

\section{HASIL PENELITIAN}

Tabel 1.

Distribusi Frekuensi Responden

Berdasarkan Umur, Pendidikan dan Riwayat Pekerjaan

\begin{tabular}{ccc}
\hline $\begin{array}{c}\text { Karakteristik } \\
\text { Responden }\end{array}$ & $\mathrm{f}$ & $\%$ \\
\hline Umur & & \\
$20-30$ & 28 & 50.91 \\
$31-40$ & 27 & 49.09 \\
Pendidikan & & \\
SD-SMP & 35 & 63.64 \\
SMA & 12 & 21.82 \\
D3-S1 & 8 & 14.54 \\
Pekerjaan & & \\
Guru & 3 & 5.45 \\
IRT & 36 & 65.45 \\
Swasta & 16 & 29.10 \\
\hline
\end{tabular}

Dari tabel di atas diperoleh informasi bahwa responden dengan kelompok umur terbanyak adalah 20-30 tahun berjumlah 28 responden (50.91\%), untuk riwayat pendidikan terbanyak adalah SDSMP berjumlah 35 responden (63.64\%). Sedangkan informasi tentang riwayat pekerjaan terbanyak adalah sebagai ibu rumah tangga berjumlah 36 responden $(65.45 \%)$.

Tabel 2.

Tabel Distribusi Frekuensi

Pengetahuan dan Pencegahan Anemia

\begin{tabular}{ccc}
\hline Variabel & $f$ & $\%$ \\
\hline Pengetahuan & & \\
Tinggi & 40 & 72.73 \\
Rendah & 15 & 27.27 \\
Pencegahan & & \\
Optimal & 28 & 50.91 \\
Kurang Optimal & 27 & 49.09 \\
\hline Jumlah & 55 & 100 \\
\hline
\end{tabular}

Dari tabel di atas dapat dicermati bahwa persentase PUS yang memiliki pengetahuan tinggi berjumlah 40 responden (72.73\%), dan yang memiliki pengetahuan rendah berjumlah 15 responden (27.27 \%), sedangkan persentasi tindakan pencegahan anemia yang dilakukan oleh pasangan usia subur secara optimal berjumlah 28 (50.91\%) dan tindakan pencegahan anemia kurang optimal berjumlah $27(49.09 \%)$.

Tabel 3.

Hasil Tabulasi Silang

Hubungan Pengetahuan tentang

Anemia dengan Tindakan

Pencegahan Anemia

\begin{tabular}{cccc}
\hline \multirow{2}{*}{$\begin{array}{c}\text { Tingkat } \\
\text { Pengetahuan }\end{array}$} & \multicolumn{2}{c}{$\begin{array}{c}\text { Pencegahan } \\
\text { Anemia }\end{array}$} & \\
\cline { 2 - 3 } & Optimal & $\begin{array}{c}\text { Kurang } \\
\text { Optimal }\end{array}$ & \\
\hline Tinggi & 28 & 12 & 0 \\
& $(50.91)$ & $(21.81)$ & 0.000 \\
Rendah & 0 & 15 & \\
& $(0)$ & $(27.27)$ & \\
\hline Total & 28 & 27 & \\
\hline
\end{tabular}

Dari hasil tabulasi silang didapakan hasil bahwa PUS yang memiliki pengetahuan tinggi dan melakukan pencegahan secara optimal adalah 28 responden sedangkan PUS yang memiliki pengetahuan rendah dan tindakan pencegahan anemia kurang optimal sebanyak 15 responden. Sedangkan hasil uji ChiSquare program SPSS versi 18.0 dengan $\alpha=5 \%(0.05)$ diperoleh $p$ sebesar 0,000 sehingga nilai $p<$ 0.05 , maka ada hubungan antara pengetahuan tentang anemia dengan pencegahan anemia.

\section{PEMBAHASAN}

Berdasarkan hasil dari penelitian ini dapat dicermati bahwa prosentasi pada responden dengan tingkat pengetahuan kategori tinggi tentang anemia terdapat 40 responden (72.73\%), sedangkan responden 
yang memiliki tingkat pengetahuan rendah terdapat 15 responden (27.27\%). Menurut Notoatmodjo (2003) yang dikutip oleh Wawan dan Dewi (2011), pengetahuan atau kognitif merupakan domain yang sangat penting untuk terbentuknya tindakan seseorang (ovent behavior). Oleh karena itu apabila seseorang mempunyai pengetahuan yang tinggi tentang anemia maka akan berdampak pada perilaku sehari-hari seperti ada kemauan untuk melakukan tindakan pencegahan anemia untuk persiapan kehamilan. Menurut Wawan dan Dewi (2011), faktor yang mempengaruhi pengetahuan meliputi faktor internal dan eksternal, adapun faktor internal meliputi pendidikan, umur dan pekerjaan. Dalam penelitian ini pendidikan terakhir yang dimiliki oleh responden paling banyak adalah SD dan SMP yaitu terdapat 35 responden (63.64\%), untuk status pekerjaan responden paling banyak adalah ibu rumah tangga terdapat 36 responden (65.45\%), sedangkan usia responden paling banyak pada usia produktif yaitu antara usia 20-30 tahun terdapat 28 responden (50.91\%). Semakin cukup umur, tingkat kematangan dan kekuatan seseorang akan lebih matang dalam berfikir dan bekerja. Dari segi kepercayaan masyarakat, seseorang yang lebih dewasa akan lebih mendapatkan kepercayaan dari orang lain apalagi didukung dengan tingkat pendidikan dan pekerjaan yang seringkali akan mendukung pengalaman dan kematangan jiwa seseorang dalam hal ini adalah melakukan tindakan pencegahan anemia untuk persiapan kehamilan.

Anemia defisiensi zat besi didefinisikan dengan rendahnya konsentrasi feritin serum $<30 \mu \mathrm{g} / \mathrm{dl}$ dan hemoglobin $<11,0 \mathrm{~g} / \mathrm{dl}$ di trimester pertama, $<10,5 \mathrm{~g} / \mathrm{dl}$ di trimester kedua dan 11,0 $\mathrm{g} / \mathrm{dl}$ di trimester ketiga. Wanita usia subur yang tidak hamil memiliki kisaran kebutuhan zat besi sebesar 1,3 $\mathrm{mg} / \mathrm{hr}$. Kebutuhan ini meningkat ketika hamil dengan kebutuhan ekstra sebesar 3,0 mg/hari terutama untuk peningkatan massa sel darah merah maternal, pertumbuhan plasenta dan janin serta mengganti kehilangan darah saat pelahiran, intestinal fisiologis, dan menstruasi di masa usia subur (Robson dan Waugh, 2011)

Kebutuhan zat besi lebih lanjut sebesar 6-8 $\mathrm{mg} /$ hari terjadi setelah 32 minggu gestasi. Wanita memiliki sekitar 2,3 gram zat besi total di dalam tubuh yang sebagian besarnya (80\%) ditemukan dalam masa sel darah merah sebagai hemoglobin $(\mathrm{Hb})$. Zat besi total didalam tubuh ditentukan oleh asupan, pengeluaran dan penyimpanan mineral ini. Zat besi yang tidak digunakan akan disimpan sebagai kompleks protein yang dapat larut yaitu feritin, yang terdapat terutama dalam hati, sumsum tulang, limpa dan otot skeletal. Dibutuhkan mekanisme absorbsi normal sistem gastrointestinal untuk mempertahankan keseimbangan antara kadar zat besi fungsional $\mathrm{Hb}$ dan zat besi yang disimpan (mioglobin). Tubuh mampu menyerap 1-2 mg zat besi setiap hari dari diet, dengan bantuan peningkat absorbsi zat besi didalam diet dan laju produksi sel darah merah yang adekuat. Faktor utama yang mengendalikan absorpsi zat besi adalah jumlah zat besi yang disimpan di dalam tubuh dan jenis zat besi yang terdapat dalam diet seseorang (Robson dan Waugh, 2011).

Fathonah (2016), menjabarkan bahwa hemoglobin merupakan zat warna yang terdapat dalam sel darah merah dan berguna untuk mengangkut oksigen dan karbon dioksida dalam tubuh. Hemoglobin 
adalah ikatan antara protein, garam besi dan zat warna. Sebagian besar ibu hamil akan mengalami beberapa tingkat anemia karena zat besi dibutuhkan untuk menghasilkan sel darah merah pada janin. Anemia bisa muncul selama kehamilan karena kekurangan asam folat. Saat kehamilan, anemia dapat dicegah atau diobati dengan menggunakan zat besi dan suplemen asam folat. Teori lain yang dikemukakan oleh Ani (2013), menjabarkan bahwa salah satu faktor yang dicurigai menjadi penyebab kegagalan suplementasi besi pada saat hamil adalah status cadangan besi tubuh kosong sejak masa prahamil. Tablet besi diberikan $60 \mathrm{mg}$ selama 16 minggu pada wanita prahamil.

Hasil penelitian ini menunjukkan bahwa responden melakukan tindakan pencegahan anemia secara optimal 28 responden (50.91\%), sedangkan tindakan pencegahan anemia kurang optimal terdapat 27 responden (49.09\%). Menurut Waryana (2016), perilaku terbuka (overt behavior) adalah respons seseorang terhadap stimulus dalam bentuk tindakan nyata atau terbuka. Respons terhadap stimulus tersebut sudah jelas dalam bentuk tindakan atau praktek (practice), yang dengan mudah dapat diamati atau dilihat oleh orang lain. Praktek (practice) manusia berasal dari dorongan yang ada dalam diri manusia, sedang dorongan merupakan usaha untuk memenuhi kebutuhan yang ada dalam diri manusia. Teori tersebut sangat sesuai dengan hasil penelitian yang sudah dipaparkan di atas bahwa apabila seseorang mempunyai pengetahuan yang tinggi tentang anemia maka akan didukung tindakan secara nyata yang bisa dilihat oleh orang lain yaitu melakukan tindakan pencegahan anemia untuk persiapan kehamilan dengan cara mengkonsumsi asam folat atau zat besi selama mempersiapkan kehamilan.

Dari hasil tabulasi silang didapatkan hasil bahwa responden yang memiliki pengetahuan tinggi dan melakukan pencegahan secara optimal terdapat 28 responden (50.91\%) sedangkan yang memiliki pengetahuan rendah dan tindakan pencegahan anemia kurang optimal terdapat 15 responden (27.27\%). Sedangkan hasil uji Chi-Square program SPSS versi 18.0 dengan a $=5 \%(0.05)$ diperoleh $p$ sebesar 0,000 sehingga nilai $p<0.05$, maka ada hubungan antara pengetahuan tentang anemia dengan tindakan pencegahan anemia. Menurut Rahmawati (2015), kebutuhan zat besi pada wanita normal sekitar 20$25 \mathrm{mg} / \mathrm{hr}$ dan ketika hamil kebutuhannya bertambah sebanyak $20 \mathrm{mg} / \mathrm{hr}$. Protein hewani, vitamin $C$, vitamin $A$, zink $(\mathrm{Zn})$, asam folat, zat gizi mikro lain dapat meningkatkan penyerapan zat besi dalam tubuh. Manfaat lain mengkonsumsi makanan sumber zat besi adalah terpenuhinya kecukupan vitamin A. Makanan sumber zat besi umumnya merupakan sumber vitamin $A$. Anemia pada ibu hamil akan menambah risiko mendapatkan bayi yang berat badannya rendah, risiko perdarahan sebelum dan pada saat persalinan, bahkan dapat menyebabkan kematian ibu dan bayi jika ibu hamil menderita anemia. Volume darah meningkat pada masa hamil seiring dengan kebutuhan zat besi. Zat besi adalah komponen utama hemoglobin, yaitu bagian darah yang mengangkut oksigen ke sel-sel tubuh dan bayi. Suplementasi zat besi semasa hamil terbukti membantu mencegah defisiensi zat besi.

Menurut Cunningham, et al, (2017) frekuensi anemia selama kehamilan bergantung terutama pada status besi sebelumnya dan suplementasi 
prenatal. Konsentrasi hemoglobin trimester pertama yang rendah, persalinan kurang bulan, dan bayi kecil untuk usia kehamilan. Koreksi anemia dan pengisian cadangan besi dapat dilakukan dengan pemberian senyawa-senyawa besi sederhana fero sulfat, fumarat atau glukonat yang memberikan sekitar $200 \mathrm{mg}$ besi elemental per hari. Jika wanita bersangkutan tidak dapat atau tidak mau minum preparat besi oral maka dapat diberikan terapi parenteral. Serupa dengan penelitian yang dilakukan oleh Iswanto (2012), berjudul hubungan pengetahuan ibu hamil tentang anemia defisiensi besi dengan kepatuhan mengkonsumsi tablet besi di Puskesmas Karangdowo Klaten. Hasil analisis dengan nilai $p$ $=0,001$. Terdapat hubungan yang signifikan antara pengetahuan ibu hamil tentang anemia defisiensi besi dengan kepatuhan mengkonsumsi tablet besi di Puskesmas Karangdowo Klaten. Penelitian lain yang setipe juga dilakukan oleh Muzayana, Santoso, dan Noviawati (2016) berjudul hubungan tingkat pengetahuan dengan kejadian anemia pada ibu hamil diwilayah Puskesmas Godean I. Hasil analisis menggunakan Chi Square menunjukkan nilai $p$ value sebesar 0,038 (< dari 0,05). Kesimpulan ada hubungan antara pengetahuan ibu hamil tentang anemia dengan pencegahan anemia.

Penelitian ini adalah replikasi dari penelitian terdahulu dimana jika seseorang memiliki pengetahuan yang rendah tentang anemia maka akan berdampak terhadap perilaku pencegahan anemia yaitu kurang mempersiapkan diri dalam menghadapi kehamilan dan tidak memperhatikan asupan zat besi disetiap diet yang dikonsumsi, sebaliknya jika seseorang memiliki pengetahuan yang tinggi tentang anemia maka akan berdampak terhadap tindakan pencegahan anemia dengan cara mengkonsumsi zat besi dan memperhatikan adanya kandungan zat besi didalam menu diet seharihari terutama untuk persiapan kehamilan, sehingga diharapkan saat terjadi kehamilan pertumbuhan dan perkembangan janin optimal serta terbebas dari risiko terjadinya bayi dengan berat badan lahir rendah ataupun perdarahan pada ibu.

\section{KESIMPULAN}

Hasil uji Chi-Square program SPSS versi 18.0 dengan $\alpha=5 \%(0.05)$ diperoleh $p$ sebesar 0,000 sehingga nilai $p<0.05$, maka ada hubungan antara pengetahuan tentang anemia dengan tindakan pencegahan anemia.

\section{SARAN}

1. Wanita usia subur selalu mengkonsumsi tablet zat besi minimal $27 \mathrm{mg} /$ hari untuk persiapan kehamilan.

2. Puskesmas dapat memberikan promosi kesehatan tentang pentingnya mengkonsumsi tablet zat besi untuk persiapan kehamilan pada pasangan usia subur.

\section{DAFTAR PUSTAKA}

Ani, Luh Seri. 2013. Anemia Defisiensi Besi Masa Prahamil \& Hamil. EGC, Jakarta.

Bakta, I Made. 2017. Hematologi Klinik Ringkas. EGC, Jakarta.

Cunningham, et., al. Obstetri Williams. Vol 2. EGC, Jakarta.

Fathonah. 2016. Gizi \& Kesehatan untuk lbu Hamil. Erlangga, Jakarta.

Fuady, Mardhatillah dan Datten Bangun. 2013. Hubungan Pengetahuan lbu Hamil tentang Anemia Defisiensi Besi terhadap Kepatuhan Mengkonsumsi Tablet Zat Besi. Vol 1. E-Journal FK 
USU. Diakses pada tanggal 19 Oktober 2017.

Iswanto, Budi. 2012. Hubungan Pengetahuan lbu Hamil tentang Anemia Defisiensi Besi dengan Kepatuhan Mengkonsumsi Tablet Besi Di Puskesmas Karangdowo Klaten. Skripsi. UMS, Surakarta.

Leveno, Kenneth J, ed. 2013. Manual Willians Komplikasi Kehamilan. Alih bahasa Herman Octavius, et al. EGC, Jakarta.

Muzayana, Addina, Sabar Santoso dan Dyah Noviawati. 2016. Hubungan Tingkat Pengetahuan dengan Kejadian Anemia pada lbu Hamil Di Wilayah Puskesmas Godean I. Vol 9. Yogyakarta. Diakses pada tanggal 11 Desember 2017.

Molika, Ewa. 2015. 275 Tanya Seputar Kehamilan \& Melahirkan. Sulis, ed. Vicasta Publishing.

Prapitasari, Erwin. 2013. Hubungan Antara Tingkat Pengetahuan Anemia dan Sikap lbu Hamil Dalam Mengkonsumsi Tablet Fe dengan Kejadian Anemia Di Wilayah Kerja Puskesmas Kerjo Kabupaten Karanganyar. Skripsi. UMS, Surakarta.
Rahmawati lis. 2015. Keperawatan Klinik VII (Sistem Reproduksi). Trans Info, Jakarta.

Robson, S. Elizabeth dan Jason Waugh, ed. 2013. Patologi Pada Kehamilan: Manajemen \& Asuhan Kebidanan. Alih bahasa Devi Yulianti. EGC, Jakarta.

Wawan, A.dan Dewi M. 2011. Pengetahun, Sikap dan Perilaku Manusia. Nuha Medika, Yogyakarta.

Waryana 2016. Promosi Kesehatan, Penyuluhan dan Pemberdayaan Masyarakat. Nuha Medika, Yogyakarta.

Wuryanti, Ayu. 2010. Hubungan Anemia Dalam Kehamilan dengan Pendarahan Postpartum Karena Atonia Uteri di RSUD Wonogiri. Tesis Pascasarjana. UNS, Surakarta.

\footnotetext{
${ }^{1}$ Dosen AKPER Panti Kosala Surakarta

${ }^{2}$ Mahasiswa AKPER Panti Kosala Surakarta
} 